Philologica Canariensia 22 (2016), 117-136 eISSN: 2386-8635

Received: 9 June 2016; revised version accepted: 18 October 2016

Published online: 25 October 2016

DOI: 10.20420/PhilCan.2016.106

\title{
EMPHATIC RECIPROCAL EXPRESSIONS AND SYMMETRIC VERBS IN SPANISH: AN EMPIRICAL ANALYSIS
}

\author{
GLÒRIA VÁZQUEZ \\ Universitat de Lleida
}

\author{
ANA FERNÁNDEZ-MONTRAVETA \\ Universitat Autònoma de Barcelona
}

\begin{abstract}
In this paper we present a descriptive study on the compatibility of emphatic reciprocal expressions with Spanish lexical reciprocal (or symmetric) verbs. Since lexical reciprocal verbs express reciprocity intrinsically, they should not require the use of an emphatic reciprocal expression to denote reciprocal meaning. Some scholars even claim that some emphatic reciprocal expressions, such as mutuamente, are incompatible. The aim of this paper is to describe to what extent symmetric verbs can be used with four of these expressions using an empirical approach. The results obtained shed light to the questions raised: we have been able to verify that these expressions are more frequent with non-reciprocal verbs and we have proved that the combination of symmetric verbs with all these expressions is possible, even in the case of mutuamente.
\end{abstract}

KEYWORDS: lexical reciprocal verbs, symmetric verbs, emphatic reciprocal expressions, reciprocity, corpus

Expresiones recíprocas enfáticas y verbos simétricos en español: un análisis empírico

RESUMEN: En este artículo presentamos un estudio descriptivo sobre la compatibilidad de las expresiones recíprocas enfáticas y los verbos recíprocos (o simétricos). En tanto que los verbos recíprocos expresan reciprocidad intrínsecamente, es previsible que no requieran el uso de una expresión recíproca enfática para expresar el significado recíproco. Algunos autores incluso defienden que algunas expresiones recíprocas enfáticas, como mutuamente, son incompatibles con estos predicados. El objetivo de este trabajo es describir hasta qué punto los verbos simétricos pueden ser usados junto con cuatro de estas expresiones, para lo cual hemos utilizado una metodología basada en corpus. Los resultados obtenidos responden a las preguntas planteadas: hemos podido verificar la más elevada frecuencia de estas expresiones con verbos no recíprocos que con predicados recíprocos y hemos probado que la combinación de estos últimos con todas estas expresiones es posible, incluso con mutuamente.

PALABRAS CLAVE: verbos recíprocos léxicos, verbos simétricos, expresiones recíprocas enfáticas, reciprocidad, corpus.

\section{INTRODUCTION}

Lexical reciprocal verbs, like conversar 'talk', chocar 'crash, collide', intercambiar(se) 'exchange', estar de acuerdo 'agree' o pelearse 'fight', are characterized by expressing intrinsically a symmetric relation between, at least, two participants and, for this reason, 
they are also called symmetric predicates. Since they express reciprocity intrinsically, hypothetically they should not require the use of an emphatic reciprocal expression (el uno con el otro 'one another / each other' or mutuamente 'mutually') to highlight the bidirectional interpretation. In this work we define emphatic reciprocal expression as the constituent that is used in one sentence in order to reinforce the reciprocal meaning of it.

Even though in previous work about reciprocal expressions in Spanish some compatibility between these expressions and reciprocal verbs has been detected (1a), not all expressions combine freely with all the predicates. In this vein, scholars agree that the expression el uno con el otro 'each other / one another' (and all the possible variants) is compatible with all the verbs in this class whereas the adverb mutuamente 'mutually' is totally incompatible (Arellano, 2004; Bosque, 1985; Peregrín Otero, 1999; Quintana, 2001 and 2013; Rodríguez Ramalle, 2005). Furthermore, the general consensus is that the cooccurrence of such expressions with reciprocal verbs is marginal whereas with non-lexically reciprocal verbs is higher $(1 \mathrm{~b})$.

(1) a. También hay que curarles de vez en cuando pequeñas heridas que se hacen ellos solos o peleándose unos con otros. (CORPES) ${ }^{1}$

'Occasionally small wounds need to be attended to. These might be self-inflicted or the result of fighting amongst themselves.'

b. ... Ferdinand Pérez, quienes aprovecharon gran parte de sus intervenciones para criticarse mutuamente. (CORPES)

'... Ferdinand Pérez, who took advantage during the greater part of their speeches to mutually criticize each other (one another).'

Thus, this paper addresses the following research questions: (i) can all Spanish reciprocal verbs be used with emphatic expressions of reciprocity?; (ii) are emphatic reciprocal expressions more commonly used with non-reciprocal verbs?; (iii) are all 4 emphatic reciprocal expressions used with all these verbs? We aim to find the most common and uncommon combinations between lexical reciprocal verbs and emphatic expressions and to describe to what extent these combinations are possible with all the verbs in the study.

The methodology used in this work is corpus-based. To our knowledge, no other study on this area bases its claims on the analysis of real sentences, and so the possibilities of combination of emphatic reciprocal expressions with reciprocal verbs have not been tested further on introspective work. We analyzed a comprehensive number of symmetric verbs and observed how they co-occur with four emphatic expressions, the two previously mentioned and two more: entre sí 'between two (or more) people' (and all the possible variants) and recíprocamente 'reciprocally'. We used two Spanish corpora, El Corpus del Español (Mark Davies, http://www.corpusdelespanol.org) and CORPES (Real Academia Española). As the results proved insufficient, we also examined the potential of using the Internet as corpus, following current proposals in corpus linguistics (Blair et al., 2002; Hundt et al., 2007; Gatto, 2014).

The results of our analysis shed light to the question raised, as we will see. On the one hand, we were able to verify the higher frequency of these expressions with non-reciprocal 
verbs; on the other, we also proved that the possibilities of combination (not their frequency) with symmetric verbs were very high.

In what follows, we first present the literature review on this topic (Section 2). In Section 3 we will explain the methodology employed, and the results will be shown in Section 4, 5 and 6: the first two deal with searches using well-established corpora for Spanish, while Section 6 presents the results found using the Internet as a corpus. Finally, in Section 7 we draw the conclusions.

\section{LITERATURE REVIEW}

From a semantic point of view, reciprocity denotes situations in which one individual acts over another and this latter individual acts over the first in just the same way (Beck, 2001; Darlympe et al., 1998; Dotlacil, 2013; Langendoen, 1978; Otte, 2004, among others). For this reason, we can say that a reciprocal event involves at least two participants and contains at least two subevents, which are performed in a symmetric manner. That is, the two participants must hold the same semantic role and must be both active and passive depending on the subevent being described. Other scholars approach reciprocity from a formal point of view by describing and comparing the way reciprocal events are expressed in languages (Dimitriadis, 2008; Evans, 2008; Frajzyngier and Curl, 1999). One of the basic issues is the fact that languages can express reciprocity through lexical items or through syntactic constructions.

The studies about the expression of reciprocity in Spanish are sparse. In this language, reciprocal constructions prototypically require a clitic; however, they are not usually described in studies dealing with pronominal constructions (De Molina, 1974; Sánchez, 2002) but are usually found as a subgroup of reflexive constructions (Gómez Torrego, 1996; Rodríguez Ramalle, 2007). Some of the most important grammatical studies review very briefly these constructions (Cano Aguilar, 1981; Martín Zorraquino, 1979). In addition, we cannot find a section devoted to reciprocal constructions in either of the two grammars by the Real Academia Española (GDLE 1999 and NGLE 2009). ${ }^{2}$ Some works that address formal characteristics of reciprocal construction in Spanish are Bosque (1985) and Quintana (2001 and 2013). Arellano (2004) and Quintana (2014) examine Spanish lexical reciprocal verbs. Also, Felíu (2003) presents an analysis of only some subgroups of symmetric verbs (those requiring a prefix).

As stated above, some authors agree that, even though the combination of emphatic reciprocal expressions with symmetric predicates is not common, it is still possible. The most compatible expression seems to be el uno con el otro. ${ }^{3}$ In fact, the possibility of occurrence of this expression is sometimes used to justify that a verb belongs to this class. According to Arellano (2004), only those verbs that admit the expression of this anaphoric element can be considered symmetric. As regards the expression entre sí 'between two or more people', the general tendency is to consider that most symmetric predicates can freely combine with it. Finally, the use of the adverb mutuamente 'mutually' is considered to be incompatible with said predicates. In this paper we aim to find evidences of the degree of certainty of these statements, since no empirical evidence has been put forward to date. 


\section{METHODOLOGY}

In what follows, we present the methodology employed in this work. First, Section 3.1 examines the general criteria used to decide if a verb should be considered a symmetric predicate. Second, Section 3.2 explains the methodology applied to select the verbs analyzed in this study and, finally, Section 3.3 is an overview of the three corpora used for the search of examples.

\subsection{Criteria used to identify the Spanish reciprocal verbs}

The first step in our research was to identify the members of the class of symmetric predicates. In order to differentiate symmetric senses of verbs from non-symmetric senses it was necessary to establish a semantic criterion: if the senses did lexically incorporate bidirectionality. A sense expresses bidirectionality when it denotes an event formed by at least 4 two symmetric subevents with two participants: in one subevent, one individual A acts over another B and, in the other subevent, the individual B acts over A in just the same manner.

(2) a. Aquella noche conversamos casi hasta que amaneció. (CORPES)

'That night we talked until dawn.'

b. Las dos mujeres se llevaban bien. Eran muy afines y se conocían desde adolescentes. (CORPES)

'Both women got along with each other. They were very alike and knew each other from teens.'

Reciprocal lexical verbs also present some formal characteristics. These characteristics are, initially, different from sentences that express reciprocity syntactically. Firstly, nonsymmetric verbs always present a plural syntactic subject (3a). Symmetric verbs, conversely, can have either a plural (2) or a singular subject (3b). This is because, unlike non-symmetric verbs, symmetric predicates can participate in the discontinuous construction (3b), in which the participants are expressed in two distinct constituents: the grammatical subject (underlined) and a prepositional complement (in square brackets).

(3) a. Como es de esperar, los legisladores se culpan uno al otro por el fracaso de la legislación. (CORPES)

'As expected, the legislators blame one another for the failure in legislation.'

b. ...el muchacho, inclinándose, intercambió [con cada invitado] un abrazo y un beso rituales. $(\mathrm{CdE})^{5}$

'The boy, leaning downwards, exchanged [with each guest] a ritual hug and a kiss.'

Secondly, non-symmetric predicates often require the use of emphatic reciprocal expressions in order to disambiguate reciprocal interpretations from reflexive. For example, if we omit the expression el uno al otro 'each other / one another' in (3a) a reflexive interpretation is also possible. The function of emphatic reciprocity expression 
with symmetric verbs (1a) is not to disambiguate reflexive from reciprocal meaning but to emphasize the latter. Thus, if we omit the expression unos con otros 'each other' in this sentence the reciprocal interpretation remains.

Finally, conversely to non-symmetric verbs, which always require the presence of a clitic when used in a reciprocal construction, lexical reciprocal verbs do not necessarily require the pronominal form. The need of a pronoun depends on individual lexical matters: for example, the symmetric predicate conversar 'talk' (2a) is a non-pronominal verb whereas llevarse bien 'get along with' (2b) incorporates a clitic (underlined).

We can conclude that the syntactic characteristics mentioned above cannot be used to identify unambiguously the class of reciprocal verbs. Firstly, having a plural subject or a pronominal form is neither an exclusive characteristic of lexical reciprocal verbs nor compulsory for this class of verbs. Secondly, we cannot rely on the co-occurrence with some adverbs or reciprocity expressions as possible formal markers since these elements can also be found in other constructions ( $3 a$ ).

Regarding the discontinuous construction, it is formally very similar to other constructions with the preposition con 'with' and a participant expressing company or instrument (Fue al cine con María 'I went to the cinema with Mary', or Abrió la botella con un cuchillo 'He opened the bottle with a knife'). Thus, if we only took form into consideration, this construction cannot help us separate symmetric verbs from other classes of predicates. Nevertheless, if we take meaning into account, only symmetric verbs will allow a reciprocal interpretation when found in this structure. In conclusion, in order to identify symmetric verbs in Spanish only semantic criteria can be applied: the lexical event has to be bidirectional and this bidirectionality is present in every context of use, that is, in any construction.

Mention should also be made of the fact that, in this study, senses are the units of analysis, and not lemmas, so whenever we discuss verbs we are discussing verb senses. For example, besar ('kiss'), as a lemma, has several senses and only some are reciprocal, such as (a) besarse en los labios ('kiss on the lips') and (b) besarse en las mejillas ('kiss each other on the cheek as a way of greeting'). Nevertheless, there is another sense of besar (c) which is not reciprocal, as in kissing someone as a sign of care, e. g. on the forehead. Although Spanish and English coincide in the senses described for besar, it might not be the case in other languages. In addition, not all the dictionaries, even for the same language, coincide in the senses defined for this verb. For example, the sense of kiss, as in joining or pressing lips together (a), is considered separately from (b) in Collins, ${ }^{6}$ whereas in Cambridge $^{7}$ they are defined together. In Spanish, DRAE $^{8}$ also only considers one sense for (a) and (b). Nevertheless, on similar occasions, this dictionary considers other symmetric senses apart from the more general sense. This is the case, for example, of the verb hablar 'talk', for which an independent reciprocal sense and a more general non-reciprocal sense are considered.

However, these senses mentioned above are commonly agreed in theoretical discussion. Nevertheless, delimiting senses proves to be an arduous task that falls beyond the scope of this paper. In this work we consider that reciprocal senses should be considered as an independent sense in dictionaries. 


\subsection{List of reciprocal verbs}

Since there was not an exhaustive list of this class of verbs, we proceeded to identify all the verbs studied in the most relevant bibliography on this topic for Spanish and then we enlarged it by translating into Spanish the examples found about this topic for other languages, including typological studies (Beck, 2001; Borillo, 1971; Darlympe et al., 1998; Dimitriadis, 2008; Dotlacil, 2013; Evans, 2008; Faller, 2007; Knjazev, 2007; Kemmer, 1993; Langendoen, 1978; Otte, 2004; Siloni, 2012, among others). Given the fact that these predicates do not share formal properties that can be used in a corpus search, corpora were mostly employed only to locate examples of use for the verbs in the list. Nevertheless, we were able to extract automatically candidates from electronic dictionaries by searching for some keywords (like recíprocamente 'reciprocally' or mutuamente 'each other') within the definitions or the examples. At the end of the process, we established a list of 138 candidates of Spanish symmetric verbs.

We further classified them basically following two criteria: their aspectual information (Aktionsart) and the argument over which bidirectionality acts. According to the first criteria, we differentiate between dynamic (such as besar 'kiss') and stative predicates (such as parecer 'look like'). As regards the second criteria, we differentiate those cases in which the mutual correspondence is established between the participants acting as grammatical subjects, as in (3), or acting as grammatical objects, as in (4):

(4) Y si mezclo el amarillo y el azul, tendré un verde. (CdE)

'And if I mix yellow and blue I will get a green'

Below we present the grouping of verbs following these criteria:

a) Aktionsart:

i. Verbs expressing actions (processes and events): $113^{9}$

ii. Verbs expressing states: $25^{10}$

b) Argument:

i. Subject: 116

ii. Objet: 22

For the analysis presented in this paper, we focused on the verbs that fulfill criteria (a.i) and (b.i), that is, we did not take into account either reciprocal verbs denoting states or reciprocal verbs expressing object reciprocity. Once we discarded the verbs with these two characteristics, the number of verbs to be analyzed was reduced to 90, from which we chose to analyze 69 predicates, which represents near $80 \%$. The reasons to proceed like this are the following:

a) Whenever a verb had more than one reciprocal sense, we decided to just take into account the most habitual sense, since searches do not allow for automatic disambiguation. Applying this criterion we discarded 16 senses.

b) Also, 5 other verb senses were discarded because their most common use corresponded to the non-reciprocal sense and the number of examples was so high that locating the reciprocal use was extremely time-consuming. This is the case of verbs such as quedar(se)-quedar ('remain / arrange to meet'), citar-citarse 
('quote / arrange to meet'), comunicar-comunicarse ('communicate / talk'), prometer-prometerse ('promise / get engaged') and ver-verse ('see / meet'). ${ }^{11}$

\subsection{Corpus}

We followed a three-phrase procedure to find examples of use with each one of the 4 emphatic reciprocal expressions for every verb under study. First, with the aim to check to what extent the frequency of co-occurrence between reciprocal expressions and nonsymmetric verbs is higher than with symmetric verbs, we consulted a medium size corpus, El Corpus del Español. Since this is a synchronous study, searches were carried out only in texts belonging to the $2 \mathrm{O}^{\text {th }}$ century, with a total of about 20 million words. We decided to use a middle size corpus since the results would not be so overwhelming and, therefore, it would facilitate the analysis of the data. In this phase we searched for instances of the 4 reciprocal expressions to discriminate the kind of verbs with which they combined.

In the second phase of the study, we used a larger corpus, CORPES, with 150 million words belonging to the $21^{\text {st }}$ century. The objective was to see the compatibilities between the 69 symmetric verbs in our study together with the 4 reciprocal expressions. Unlike in the previous phase, we were only interested in analyzing examples of symmetric verbs.

Both corpora are lemmatized, which is extremely beneficial in order to simplify the searches. In the searches for reciprocal expressions the option 'span' has also been very useful. Thus, the interface potential has helped us reduce the number of patterns searched. Regarding the reciprocal expressions under study, the search for adverbs was quite simple since they only have one invariable form. However, in the case of the other two expressions we had to consider all the possible combinations. Thus, on the one hand, we searched for the preposition entre 'between/among' combined with different pronouns: entre sí 'each other', entre nosotros/as 'between/among us', entre vosotros/as between/among you' and entre ellos/as 'between/among them'. On the other hand, to search for the expression el uno con el otro 'each other / one another', we had to use a versatile search pattern to account for all the possible variations: (i) determiners ( $\mathrm{el}$ 'the') can sometimes be left out (uno con otro); (ii) it accepts changes in gender (feminine vs. masculine) and number (singular vs. plural) ((la) una con (la) otra / (los) unos con (los) / (las) unas con (las) otras); and (iii), even though the prototypical preposition used in this expression is con 'with', we have observed that other prepositions such as a 'to', contra 'against' y de 'of' have also been found in the corpus consulted (5). ${ }^{12}$

(5) a. ...éstas (las células) se llenan de aire y se unen unas a otras formando un tejido flojo y ligero. (CORPES)

'... these (the cells) fill with air and join together forming a loose light tissue.'

b. Luchaban uno contra otro de forma muy violenta, muy poco noble y sin un ideario digno de respeto. (CORPES)

'They battled one another in a violent, not very noble way and without an ideology worthy of respect.'

c. No lograba distinguir uno de otro. (CdE)

'He failed to distinguish between them.' 
In the third phase, we repeated the searches conducted in phase 2 but using the Internet as a corpus. The advantage of this methodology is that it allows us to obtain results of linguistic phenomena that are not so frequent in canonical corpora. Some scholars started using the Internet as a corpus some years back with the objective of accessing a much higher quantity of words from diverse registers at once. Thus, the use of the Internet as a corpus has been defended from several areas. Hundt et al. (2007) underlines the benefits of the Internet as a corpus comparing it with really big reference corpora, such as BNC. They see the Internet as a valuable resource for the enormous and varied amount of data it can provide concerning several fields such as morphological productivity, the study of word frequency (Blair et al., 2002) and a broad range of research questions. The use of the Internet as a corpus has also been postulated to better explore lexical uses (Álvarez, in press). Another related field that promotes the use of the Internet is the area of language teaching, in which the World Wide Web can be used to verify the use of some words in context (Cruz Piñol, 2012; Humblé, 2001; Sala Caja 2004).

Using the Internet as a corpus presents many advantages but also some drawbacks. First, as we have said, the quantity of data available is clearly much higher and, thus, the qualitative analysis of the results is more time-consuming. Secondly, the search for examples on the Internet is based on words so the strategy was necessarily different, since searches by lemma were not possible. Thirdly, on the Internet one can also find many marginal uses and even errors, in the sense that the texts might not be written by a proficient or a native speaker and they might not have been published with any further edition. It is precisely for this reason that the linguists analyzing the data found on the web must filter hits according to their knowledge. This is the procedure used in this study and we believe it is perfectly valid, since our aim is to decide if a particular combination of words sounds natural. In case of doubt, we always opted for finding further evidence about the feasibility of a combination. We also established a second filter to ensure the suitability of the instances by giving priority to examples from sufficiently reliable sources such as press articles or books with an ISBN. This requisite slowed down the analysis a little bit since not always the results shown first fulfilled this criterion and therefore we had to revise more sentences until we found a reliable source.

In the next sections we are going to describe the results obtained in each phase. As will be seen, the results of each level have constituted the motivation for the next.

\section{CORPUS DEL ESPAÑOL}

In a first phase, we searched for all the 4 emphatic reciprocal expressions on their own, without looking for specific verbs. From the total sentences obtained $(3,299)$, we studied a sample of 443 , approximately $15 \%$ of all the sentences. As can be observed in Table 1, from these 443 sentences, 49 were discarded because they did not denote reciprocal situations. ${ }^{13}$ From the 394 sentences analyzed we observed that only $22.34 \%$ were expressions that co-occur with symmetrical verbs. This fact allows us to state that emphatic reciprocal expressions are more common with non-reciprocal verbs (77.66\%), as noted in the existing bibliography. 


\begin{tabular}{|l|c|}
\hline Sentences analyzed & $\begin{array}{c}443 \text { (from 3,299) } \\
(13.42 \%)\end{array}$ \\
\hline Non-reciprocal uses & $\begin{array}{c}49 \\
(11.06 \%)\end{array}$ \\
\hline Reciprocal uses & 394 \\
Reciprocal uses with symmetric verbs & $(88.94 \%)$
\end{tabular}

Table 1. Distribution of the uses of the reciprocal expressions with symmetric verbs and non-symmetric verbs in the Corpus del Español

In Table 2 we present the figures for each expression independently. As can be observed, entre... is the most frequent expression by far, followed by [(DET) uno* PREP (DET) otro* ${ }^{*}$, the adverb mutuamente and, finally, the adverb recíprocamente. In order to analyze the examples, we established the following criteria: if the number of sentences was low, all of them were taken into consideration; otherwise, when the amount of sentences was too high, we selected a representative number of examples. Thus, we analyzed 200 sentences with the expression entre... and 100 sentences with the expression [(DET) uno* PREP (DET) otro* ${ }^{*}$. All the sentences with the two adverbs were analyzed.

\begin{tabular}{|c|c|c|c|c|}
\hline & $\begin{array}{c}\text { (DET) uno }{ }^{*} \\
\text { PREP (DET) otro* }\end{array}$ & entre... & mutuamente & recíprocamente \\
\hline Total of sentences & $\begin{array}{c}550 \\
(16.67 \%) \\
\end{array}$ & $\begin{array}{c}2,606 \\
(78.99 \%) \\
\end{array}$ & $\begin{array}{c}126 \\
(3.82 \%) \\
\end{array}$ & $\begin{array}{c}17 \\
(0.52 \%) \\
\end{array}$ \\
\hline Analyzed & $\begin{array}{c}100 \\
(18.18 \%)\end{array}$ & $\begin{array}{c}200 \\
(7.67 \%)\end{array}$ & $\begin{array}{c}126 \\
(100 \%)\end{array}$ & $\begin{array}{c}17 \\
(100 \%)\end{array}$ \\
\hline Reciprocal uses & $\begin{array}{c}100 \\
(100 \%)\end{array}$ & $\begin{array}{r}152 \\
(76 \%) \\
\end{array}$ & $\begin{array}{c}126 \\
(100 \%) \\
\end{array}$ & $\begin{array}{c}16 \\
(100 \%)\end{array}$ \\
\hline $\begin{array}{l}\text { With non- } \\
\text { symmetric verbs }\end{array}$ & $\begin{array}{c}93 \\
(93 \%)\end{array}$ & $\begin{array}{c}75 \\
(49.34 \%)\end{array}$ & $\begin{array}{c}125 \\
(99.21 \%)\end{array}$ & $\begin{array}{c}14 \\
(87.5 \%)\end{array}$ \\
\hline $\begin{array}{l}\text { With symmetric } \\
\text { verbs }^{14}\end{array}$ & $\begin{array}{c}7 \\
(7 \%)\end{array}$ & $\begin{array}{c}77 \\
(50.66 \%)\end{array}$ & $\begin{array}{c}1 \\
(0.79 \%)\end{array}$ & $\begin{array}{c}2 \\
(11.76 \%)\end{array}$ \\
\hline
\end{tabular}

Table 2. Results of the search for each of the 4 emphatic expressions of reciprocity in the Corpus del Español 
The absolute data reflected in Table 2 for the expressions mutuamente and recíprocamente combined with symmetric verbs are really low (1 and 2 occurrences respectively). However, the fact that we obtained some examples of these combinations shed light on the possibility of such adverbs co-occurring with reciprocal verbs, contrary to the requirement hypothesized by some scholars working in this area. In (6) we present the three examples. ${ }^{15}$

(6) a. ...las partículas cargadas negativamente, como los electrones, que también se repelen mutuamente.

'... negatively charged particles, like electrons, that also repel each other.'

b. Lo que produce cada familia se le presenta como productos diversos de su trabajo, y luego como mercancías que se cambian recíprocamente.

'What each family produces is presented as diverse products from their work, and then as goods that are exchanged among them.'

c. ...los cuerpos se atraen recíprocamente con una fuerza que varía inversamente al cuadrado de la distancia entre ellos.

'... bodies attract each other with a force that varies inversely to the square of the distance between them.'

Regarding the other two expressions, the combination of the expression entre... with symmetric verbs is clearly predominant with respect to [(DET) uno* PREP (DET) otro*] (50.66\% vs. 7\%), contrary to the theoretical predictions presented in Section 2, where the latter expression was considered the reciprocal expression per excellence when combined with this class of predicates.

\section{CORPES}

In this section we will focus exclusively on determining with greater certainty the possibilities of combination of these 4 reciprocity expressions with symmetric verbs. Thus, in this phase of the study we were not as interested in frequency as we were in the possibility of their co-occurrence with a symmetric predicate. In order to fulfill this objective, we searched a larger corpus for appearances of all 69 verbs (lemmas) under consideration together with each one of the 4 reciprocity expressions. Results are presented in Table 3.

\begin{tabular}{|c|c|c|c|}
\hline $\begin{array}{c}\text { (DET) } \text { uno }^{*} \\
\text { PREP (DET) } \text { otro* }^{*}\end{array}$ & entre... & mutuamente & recíprocamente \\
\hline 30 verbs & 54 verbs & 13 verbs & 4 verbs \\
$(43.48 \%)$ & $(78.26 \%)$ & $(18.84 \%)$ & $(5.80 \%)$ \\
\hline
\end{tabular}

Table 3. Co-occurrence of symmetric verbs and emphatic reciprocity expressions in the CORPES 
As can be observed, the results obtained are quite similar in both corpora. First, the primacy of the expression entre... over the rest is confirmed. Second, the low frequency of [(DET) uno* PREP (DET) otro*] is also corroborated. Third, at least some lexical reciprocal verbs do combine with the expression mutuamente and, to a lesser extent, with recíprocamente. In the light of the data, it does not appear to be feasible to provide a theory to explain the reason why some verbs are found in combination with some expression whereas other verbs are not. Thus, we have confirmed that a verb such as chismorrear 'gossip' combines with the expression entre... (7); the question is to what extent other verbs, specially those semantically related such as cotillear 'gossip', do not allow to the combination with that expression.

(7) En el otro extremo del salón, las alegres nietas chismorrean entre sí de chicos.

'In the other end of the room, the merry granddaughters gossip among themselves about boys.'

This lack of discrepancy in the behavior between synonymous or quasi-synonymous verbs (chismorrear and cotillear 'gossip') is surprising (see Section 5), but it is also surprising that other combinations that would sound natural for a native speaker (using introspective knowledge of the language) do not appear. This is the case of congeniar 'get along / get on' and the expression [(DET) uno* PREP (DET) otro*]. The said combination has not been identified in the corpus but it would be possible to utter a sentence with both elements together (8).

(8) En esta clase los alumnos congenian muy bien unos con otros.

'In this classroom, students get on really well with each other.

Another surprising fact that comes from the analysis of the data in Table 3 is the difference in use between mutuamente and recíprocamente, since they are practically identical adverbs. The higher frequency of the former with respect to the latter is indicated by the results, even though the combination with reciprocamente is possible, from introspective knowledge. The issue we would like to clarify is to what extent the explanation to this absence of examples in the corpus is related to the incompatibility of these elements or to the low frequency of use of emphatic reciprocal expressions with symmetric verbs. In order to answer this question, we searched over the Internet for instances of said co-occurrences.

\section{GOOGLE}

In this section we present the data obtained when using the Internet as a corpus. As can be observed, the figures vary considerably from the ones seen previously, contrarily to other studies where the results obtained using the Internet were rather similar than those obtained using corpora (Blair et al., 2002).

Table 4 shows that we found at least one example for all the verbs in our analysis (100\%) combining with both expressions entre... and [(DET) uno* PREP (DET) otro*]. In 
addition, almost $93 \%$ of these predicates also combine with mutuamente and almost $71 \%$ with recíprocamente.

\begin{tabular}{|c|c|c|c|}
\hline $\begin{array}{c}\text { (DET) } \text { uno }^{*} \\
\text { PREP (DET) } \text { otro* }^{*}\end{array}$ & entre... & mutuamente & recíprocamente \\
\hline 69 & 69 & 64 & 50 \\
$(100 \%)$ & $(100 \%)$ & $(92.75 \%)$ & $(72.46 \%)$ \\
\hline
\end{tabular}

Table 4. Results of searches using the Internet as corpus

If we take into account that searches on the Internet were based on forms (not lemmas), these results prove more relevant. In the case of verbs, we always search for the $3^{\text {rd }}$ person plural of verb in the present simple indicative. Regarding the expressions, the searches were not so problematic since the two adverbs are invariable. In the case of the entre expression, we prioritize $3^{\text {rd }}$ person forms (sí, ellos and ellas). For the expression [(DET) uno* PREP (DET) otro*] searches were restricted to masculine forms even though we searched all the other variants.

The use of the Internet as a corpus has allowed us to get hits with some verbs that were not present in the other two corpora used. This is due to the fact that the size of the corpora is not comparable to all the content existing on the net. Next (Section 5.1), we present some examples of the kind of sentences found using the Internet and that have not been found in the other two corpora. In Section 5.2 we examine more closely the potential incompatibilities between the two adverbs.

\subsection{Analysis of the contexts}

We would like to point out that in the cases in which we found examples of combinations on the Internet that were not present in the other corpora, we were not able to identify a specific context of use that might provide a plausible explanation. That is, all the other combinations sound natural to a native speaker and we believe it is rather surprising that they did not appear in the other corpora. This is, for example, the case of the verb compenetrarse (9) that has been only detected in combination with the four expressions under study on the Internet.

(9) a. La amistad y el odio se compenetran el uno con el otro, oponiéndose y uniéndose. 'Friendship and hate blend together, opposing and attracting each other.'

b. Los estilos de la descripción literaria se compenetran y armonizan entre sí, pero las formas y los géneros mantienen sus peculiaridades.

'Although the methods of literary description are mixed and harmonized with each other, each form or genre retains its own characteristics.

c. La formación es un proceso integral cuyos elementos se compenetran mutuamente.

'Formation is an integral process whose elements inter-penetrate one another.' 
d. Fe, culto y ethos se compenetran recíprocamente como una sola realidad.

'Faith, worship and ethos are interwoven as a single reality.'

Thus, we have also seen that using only regular corpora limits somehow the results whereas appropriately using the Internet as a corpus helps us overcome these limitations. Only on occasion, the search on the Internet has helped us to exemplify some combinations that were originally difficult to imagine. This is the case, for example, of the verbs acostarse (10) y casarse (11) in the sentences below:

(10) ... se habían besado, hablaron como amantes, se acostaron el uno con el otro y despertaron en los brazos del otro con alegría.

'... they had kissed, talked like lovers, and got laid, and they woke up in each other arms with joy.'

(11) a. ... dado que los miembros de ciertos grupos preferentemente se casan entre sí.

'... since the members of certain groups prefer to marry among themselves.'

b. Dos hombres viudos, cada uno con una hija casadera, que se casan "mutuamente"16 con la hija del otro.

'Two widowed men, each one with a daughter of marriageable age, that marry mutually with the other's daughter.'

We have observed that the specific context of multiple reciprocity, exemplified in (11) and (12), favors the expression of these emphatic expressions with symmetric verbs. Multiple reciprocity is characterized by the presence of more than two participants in more than 2 subevents (Fernández-Montraveta and Vázquez, 2016).

(12) a. Los hombres se dan la mano unos con otros para mostrar una forma de amistad.

'Men shake hands among themselves to show a friendship form.'

b. Hombres y mujeres se besan entre ellos en los labios.

'Men and women kiss amongst themselves on the lips.'

Last, the metaphorical use also promotes the combination of verbs and reciprocal expressions that might not seem possible at first, as can be seen in (13). In (13a) the metaphorical use and the multiple reciprocity interpretations coincide.

(13) a. Indicó que México ni ningún país del mundo podría salir de esta crisis si sus habitantes no se dan la mano uno con otro.

'He indicated that neither Mexico nor any other country in the world would come out of the crisis unless its people learn to cooperate with each other.'

b. Nuestras vidas están hechas de diferentes caras, que armonizan entre sí de forma fluida.

'Our lives are made of different sides that seamlessly blend one into the other.' 


\subsection{The adverbs mutuamente and recíprocamente}

The adverbs mutuamente and recíprocamente were the only reciprocal expressions that showed some potential incompatibilities (see Table 5) in our previous search. We decided to broaden the search performed with these two reciprocal expressions, the adverbs mutuamente and recíprocamente, and search for their co-occurrence with more verbs than just the ones considered originally with the idea of shedding light on possible causes for the incompatibilities found. We have grouped the verbs into 8 semantically related classes to compare the behavior of these adverbs.

\begin{tabular}{|c|c|c|c|c|}
\hline & $\begin{array}{l}\text { SEMANTIC } \\
\text { GROUPS }\end{array}$ & SYMMETRIC VERBS & mutuamente & recíprocamente \\
\hline $\mathbf{A}$ & Sexual Relation & acostarse ('sleep with someone') & $x$ & $x$ \\
\hline & & hacer el amor ('make love') & $\checkmark$ & $x$ \\
\hline & & copular ('copulate') & $\checkmark$ & $\checkmark$ \\
\hline $\mathbf{B}$ & General & charlar ('chat') & $x$ & $x$ \\
\hline & Communication & conversar ('converse') & $\checkmark$ & $x$ \\
\hline & & $\begin{array}{l}\begin{array}{l}\text { intercomunicarse } \\
\text { another') }\end{array} \\
\text { ('talk to one }\end{array}$ & $\checkmark$ & $x$ \\
\hline & & hablar ('talk') & $\checkmark$ & $\checkmark$ \\
\hline & & dialogar ('dialogue') & $\checkmark$ & $\checkmark$ \\
\hline & & discutir ('discuss') & $\checkmark$ & $\checkmark$ \\
\hline $\mathbf{C}$ & Specific & chismorrear ('gossip') & $x$ & $x$ \\
\hline & Communication & cotillear ('gossip') & $\checkmark$ & $x$ \\
\hline & & cuchichear ('gossip') & $\checkmark$ & $x$ \\
\hline $\mathbf{D}$ & Marriage Act & divorciarse ('divorce') & $x$ & $x$ \\
\hline & & casarse ('get married') & $\checkmark$ & $\checkmark$ \\
\hline $\mathbf{E}$ & Positive Relation & hacer las paces & $x$ & $x$ \\
\hline & & reconciliarse ('reconcile') & $\checkmark$ & $x$ \\
\hline & & estar de acuerdo ${ }^{17}$ ('agree') & $\checkmark$ & $x$ \\
\hline $\mathbf{F}$ & Negative & pelearse ('fight') & $\checkmark$ & $x$ \\
\hline & & reñir ('scold') & $\sqrt{ }$ & $x$ \\
\hline & & rivalizar ('rival') & $\sqrt{ }$ & $x$ \\
\hline & & $\begin{array}{l}\text { no hablarse ('not to talk to each } \\
\text { other') }\end{array}$ & $\checkmark$ & $x$ \\
\hline & & estar en desacuerdo ('disagree') & $\checkmark$ & $x$ \\
\hline $\mathbf{G}$ & Alternating & turnarse ('take turn') & $\checkmark$ & $x$ \\
\hline & Relation & alternarse ('alternate') & $\checkmark$ & $\checkmark$ \\
\hline $\mathbf{H}$ & Relationships & rimar ('rhyme') & $\checkmark$ & $x$ \\
\hline & & congeniar ('get along') & $\checkmark$ & $x$ \\
\hline & & avenirse ('get on well with') & $\checkmark$ & $\checkmark$ \\
\hline & & coincidir ('coincide') & $\checkmark$ & $\checkmark$ \\
\hline
\end{tabular}

Table 5. Possibilities of combination of verbs with mutuamente and recíprocamente using the Internet as corpus 
We can observe that recíprocamente does not combine with any of the predicates in 3 out of the 8 groups. This is the case of the verbs of specific communication (C), and verbs expressing a positive (E) or a negative (F) relationship. Besides, in all the other groups at least half the predicates have not been found combined with this adverb. The combination with the adverb mutuamente is somewhat different since the 5 verbs that do not combine with it do not belong to the same group. Generally speaking, we have not observed a clear reason that allows us to account for the different behavior observed with respect to the combinatorial possibilities of (i) an adverb with verbs semantically related, (ii) a verb with both adverbs and (iii) a given verb with the other expressions of reciprocity under study.

With respect to (i), only in the case of the adverb reciprocamente a tendency in the behavior between semantic grouping of verbs and its use is observed. Since this adverb is formal, it does not combine freely with informal verbs (like acostarse 'make love' or cotillear 'gossip'), but it is also true that it presents incompatibilities with some formal predicates (conversar 'converse', rivalizar 'rival' or estar en desacuerdo 'disagree'). In the same vein, we do not come up with a reason to explain why mutuamente can combine with alternarse ('alternate') (14) but cannot with turnarse ('take turns').

$$
\begin{aligned}
& \text { (14) ... la fortuna es versátil y los males y las tristezas se alternan mutuamente } \\
& \text { '...fortune is versatile and bad and sad things alternate mutually' }
\end{aligned}
$$

In the same way, regarding (ii), we cannot think of a justification why we can use conversar together with mutuamente (15) but we cannot with recíprocamente, when hablar can combine with both adverbs (16) and charlar with neither one.

(15) ... que coexisten y conversan mutuamente al mismo estilo no lineal del universo.

'... that coexist and mutually converse in the same non-lineal style of the universe.'

(16) a. A menudo, existe una comunicación más eficaz con los hijos, por la forma en que los padres se escuchan y se hablan mutuamente.

'Quite often, there exists a more effective communication with children depending on the way parents listen and talk to each other.'

b. Cuantas veces oigas, pues, o leas que el Verbo y el alma se hablan recíprocamente y que mutuamente se miran...

'As many times you hear, then, or read that the Verb and the soul talk to each other and that they mutually look at each other...'

Lastly (iii), we cannot point out the reason why charlar combines with the expressions [(DET) uno* PREP (DET) otro*] and entre... (17), but it does not with any of the adverbs denoting reciprocity.

(17) a. En las terrazas, varios jóvenes toman cerveza y charlan unos con otros.

'In the terraces, several young people drink beer and talk among them.'

b. ... se relajan y bromean y charlan entre sí.

'... they let loose and joke and chat with each other.' 
In our opinion, the only explanation that we can contribute in the light of the data presented in (14)-(17) is that the incompatibilities observed must be due to use.

\section{CONCLUSIONS}

In this paper we have analyzed the co-occurrence of 4 prototypical reciprocal expressions ([(DET) uno* PREP (DET) otro* ${ }^{*}$, entre sí / nosotros-as, vosotros-as, ellos-as, mutuamente and recíprocamente) with 69 symmetric verbs in Spanish, which represent $80 \%$ of symmetric verbs in Spanish. Our aim was to see to what extent lexical reciprocal verbs and emphatic expressions combine.

Our data was extracted from two well-established corpora for Spanish. In addition, we also used the Internet as a more comprehensive corpus for further input. We observed that the combination of mutuamente with the verbs analyzed is particularly low if we only take into account the results obtained in the corpus CORPES (less than 20\%), whereas on the Internet we found combinations of this adverb with $92.75 \%$ of the verbs. Accordingly, in our canonical corpora the expression [(DET) uno* PREP (DET) otro*] was only documented, quite surprisingly, in combination with less than $45 \%$ of the verbs in this corpus. Using the Internet we have found this reciprocal expression combined with all the verbs of our study. We have also seen that the expression entre... combines more freely with symmetric verbs than expected and also that it collocates with the same verbs as [(DET) uno* PREP (DET) otro* ${ }^{*}$. In this sense, a contribution of this paper to the area of corpus linguistics has been to prove how the use of regular corpora can limit the results and how appropriately using the Internet as a corpus can help to overcome these limitations.

In a qualitative analysis of the data, we have observed that even though sometimes the use of emphatic expressions with symmetric verbs might seem redundant, they still constitute a linguistic resource to emphasize the symmetric relation, for example in those cases in which the verb is used metaphorically or in which we find a multiple reciprocal situation. The possibility of combining symmetric verbs with other possible expressions of reciprocity, such as the adjective juntos or the adverb conjuntamente, still remains to be analyzed. In a preliminary study we have located a significant number of sentences exemplifying these combinations even though the number of examples seems considerably lower than the combinations analyzed in this paper.

\section{NOTES}

1 Corpus del Español del Siglo XXI, http://www.rae.es/recursos/banco-de-datos/corpes-xxi.

2 In both cases the analysis of reciprocity is limited to a subsection devoted to reciprocal pronouns. In the case of GDLE, the section was written by Peregrín Otero (1999) (chapter 23, 1427-1517).

3 Devis Márquez (2006) disagrees with this proposal since he characterizes symmetric verbs as those that do not combine with emphatic expressions, or at least they do not with the one mentioned in the text.

4 There may be more than two participants; if this is the case, we observe two possible behaviors: participants can be grouped as two, so there are also just two subevents ("Portugueses y 
holandeses compitieron por la influencia en la región (...).” (CdE) ['The Portuguese and Dutch competed for dominance of the region (...).']), or they can act as several denoting in this case more than one event ("Después que todos nos saludamos entre sí subimos a la nave (...)." (CdE) ['After we all greeted each other, we boarded the ship (...).']).

6 http://www.collinsdictionary.com/dictionary/english. [Accessed 29 September 2016].

7 http://dictionary.cambridge.org/es/diccionario/ingles/kiss. [Accessed 29 September 2016].

8 http://dle.rae.es/. [Accessed 29 September 2016].

9 We have followed Vendler's (1967) traditional classification and subsequent adaptations (Van Voorst, 1992), in which verbs with an Experiencer in subject position are considered processes. Thus, we consider verbs, such as compenetrarse 'understand each other' and llevarse bien $/ \mathrm{mal}$ '(not) get along (well)', actions.

We have accounted for 25 Spanish stative predicates that express reciprocity lexically but only 5 of them are isolated verbs (parecerse 'be alike', 'look alike', asemejarse 'resemble', diferenciarse 'be different', tocarse 'be close to', equivaler 'be equivalent'). All the rest are verbal locutions made by ser or estar 'be' (such as ser novios 'be dating', estar casados 'be married', estar al lado 'be next to' and estar cerca 'be near', etc.).

11 In the last four cases, the reciprocal sense is pronominal but in the non-reciprocal sense we also find a pronoun when the verb is used in the passive pronominal structure, such as in "Entre las medidas prohibitivas se citan las de fiestas públicas que contemplen el cierre de calles" [CdE] ('Among the prohibitive measures the ones related to the public festivities that require closing the streets to traffic are mentioned'). Compare it with the lexical reciprocal use of citarse: "Jorge y Laura regresan porque en este hotel se citaron la primera vez y se hizo costumbre" [CdE] ('Jorge and Laura are coming back because in this hotel they arranged to meet for the first time and it became a habit.').

12 In order to account for this variability we will refer to this construction from now on with the schematic expression: [(DET) uno* PREP (DET) otro*], in which categories are expressed in capital letters, optionality is expressed in brackets, italics is used to mark lexical words and the star to represent the lemmas.

13 Sentences with non-reciprocal uses contain instances with the expression entre..., ('among'...) as in: "Varias personas, entre ellas Carmen Balcells..." [CdE] 'Several people, among them Carmen Balcells...'. We also identify an example with the adverb recíprocamente used metalinguistically.

14 The total number includes symmetric verbs expressing both reciprocity in the subjects or the objects, because this differentiation was not relevant in this phase. In any case, we specify the number of sentences expressing reciprocity of subject: 4 out of 7 for the first expression, 39 out of 77 for the second and all sentences for the other two expressions.

15 In chemistry, repeler ('repel') and atraer ('attract') are only understood expressing a symmetric relation (see DRAE).

16 The use of quotes in this sentence seems to represent that this adverb is perceived as uncommon by the author. 


\section{REFERENCES}

ÁLVAREZ, E. (in press). "Uso y desuso del corpus con fines lexicográficos: ¿̇crónica de una muerte anunciada?”. Actas del $7^{\circ}$ Congreso de la Asociación Española de Lingüística de Corpus (AELINCO 2015). Procedia - Social and Behavioral Sciences.

ARELLANO GONZÁLEZ, B. 2004. "Los verbos simétricos", Verba, 31, 325-359.

BECK, S. 2001. "Reciprocals are Definites”, Natural Language Semantics 9 (1), 69-138.

BLAIR, I. V., URLAND, G. R. and MA, J. E. 2002. "Using Internet Search Engines to Estimate Word Frequency", Behavior Research Methods, Instruments, \& Computers, 34 (2), 286-290.

BORILLO, A. 1971. "Remarques sur les verbes symmetriques français", Langue Française, $11,17-31$.

BOSQUE, I. 1985. "Sobre las oraciones recíprocas en español", Revista Española de Lingüística, XV (1), 59-96.

CANO AGUILAR, R. 1981. Estructuras sintácticas transitivas en el español actual. Madrid: Gredos.

CRUZ PIÑOL, M. 2012. Lingüística de corpus y enseñanza de español como 2/L. Madrid: Arco Libros.

DARLYMPE, M., KANAZAWA, M., KIM, P. Y., MCHOMBO, S. A. and PETERS, M. S. 1998. "Reciprocal Expressions and the Concept of Reciprocity", Linguistics and Philosophy, 21, 159-210.

DE MOLINA, J. A. 1974. Usos de "se". Cuestiones léxicas y sintácticas. Madrid: Sociedad General Española de Librería (SGEL).

DEVIS MÁRQUEZ, P. 2006. "Reciprocidad y alternancias diatéticas en español”, Zeitschrift fur Romanische Philologie, 122 (3), 445-514.

DIMITRIADIS, A. 2008. "Irreducible Symmetry in Reciprocal Constructions", in König, E. and Gast, V. (eds.), Reciprocals and Reflexives: Theoretical and Typological Explorations (Trends in linguistics. Studies and Monographs 192). Berlin, New York: Mouton de Gruyter, 375-409.

DOTLACIL, J. 2013. "Reciprocals Distribute over Information States", Journal of Semantics, 30, 423-477.

EVANS, N. 2008. "Reciprocal Constructions: Towards a Structural Typology", in König, E. and Gast, V. (eds.), Reciprocals and Reflexives: Theoretical and Typological Explorations (Trends in linguistics. Studies and Monographs 192). Berlin, New York: Mouton de Gruyter, 33-103.

FALLER, M. 2007. "The Ingredients of Reciprocity in Cuzco Quechua", Journal of Semantics, 24 (3), 255-288.

FELÍU ARQUIOLA, E. 2003. Morfología derivativa y semántica léxica: la prefijación de auto-, co- $e$ inter-. Madrid: UAM Ediciones.

FERNÁNDEZ-MONTRAVETA, A. and VÁZQUEZ, G. 2016 (in press). “The Event Structure of Reciprocal Verbs and its Implications for Bidirectionality", Signos, 49 (92).

FRAJZYNGIER, Z. and CURL, T. S. 1999. Reciprocals. Forms and Functions. Amsterdam/Philadelphia: John Benjamins.

GATTO, M. 2014. The Web as Corpus: Theory and Practice. London: Bloomsbury. 
[GDLE] BOSQUE, I. and DEMONTE, V. (eds.). 1999. Gramática descriptiva de la lengua española. Madrid: Espasa Calpe.

GÓMEZ TORREGO, L. 1996. Valores gramaticales de "se". Madrid: Arco Libros.

HUMBLÉ, P. 2001. "O uso de corpora no ensino de línguas. Alguns exemplos do portuguêse do español”, in Cabral, L. M., Souza, P., Lopes, R. E. and Pagotto, E. G. (orgs.), Lingüística e Ensino: Novas Tecnologías. Blumenau: Nova Letra, 157-180.

HUNDT, M., NESSELHAUF, N. and BIEWER, C. (eds.). 2007. Corpus Linguistics and the Web. Amsterdam: Rodopi.

KEMMER, S. 1993. The Middle Voice. Amsterdam/Philadelphia: John Benjamins.

KNJAZEV, J. P. 2007. "Lexical Reciprocals as a Means of Expressing Reciprocal Situations", in Nedjalkov, V. P. (ed.), Reciprocal Constructions. Amsterdam: John Benjamins, 114-146.

LANGENDOEN, D. T. 1978. “The Logic of Reciprocity”, Linguistic Inquiry, 9 (12), 177-197.

MARTÍN ZORRAQUINO, M. A. 1979. Las construcciones pronominales en español. Madrid: Gredos.

[NGLE] Real Academia Española. 2009. Nueva gramática de la lengua española. Madrid: Espasa-Calpe.

OTTE, R. A. 2004. A Semantic Analysis of Reciprocal Expressions. An Alternative Approach to Reciprocity. MA thesis. Tilburg: University of Tilburg.

PEREGRÍN OTERO, C. 1999. "Pronombres reflexivos y recíprocos", in Bosque, I. and Demonte, V. (eds.), Gramática descriptiva de la lengua española. Madrid: Espasa Calpe.

QUINTANA, L. 2001. El papel de la estructura argumental en las construcciones recíprocas del inglés y del español. $\mathrm{PhD}$ thesis. Sevilla: Universidad de Sevilla. 2013. Construcciones recíprocas. Madrid: Arco Libros.

. 2014. "Verbos recíprocos", Dicenda. Cuadernos de Filología Hispánica, 32, 265-312.

RODRÍGUEZ RAMALLE, T. 2005. Manual de sintaxis del español. Madrid: Castalia. . 2007. "Notas sobre la reflexividad y reciprocidad en español", Hesperia. Anuario de Filología Hispánica, X, 189-206.

SALA CAJA, L. 2004. "Aliarse con Internet para aprender (sobre el) vocabulario", Carabela, 56, 121-143.

SÁNCHEZ, C. (ed.). 2002. Las construcciones con "se". Madrid: Visor Libros.

SILONI, T. 2012. "Reciprocal Verbs and Symmetry", Natural Language Theory, 30, 261-320.

TARP, S. (in press). "El análisis de corpus es una ceremonia superflua y una forma de malgastar tu tiempo y el dinero del gobierno". Actas del $7^{\circ}$ Congreso de la Asociación Española de Lingüística de Corpus (AELINCO 2015). Procedia - Social and Behavioral Sciences.

\section{ABOUT THE AUTHORS}

Glòria Vázquez is Associate Professor at the Universitat de Lleida (Spain) and Ana FernándezMontraveta is Associate Professor at the Universitat Autònoma de Barcelona (Spain). Both 
researches share a common interest centered around the description of the verbs as the nuclear elements of sentences. More precisely, they are interested in the description of the syntacticosemantic interface. Among their more than 50 publications in common, their book Clasificación verbal. Alternancias de diátesis (2000) stands out together with several articles published in high-impact international journals. Shortly, the book Construcciones pronominales con se will be published as a volume in the collection Cuadernos de Lengua Española by Arco Libros.

\section{ORCID}

Glòria Vázquez: 00o0-0002-7673-7610

Ana Fernández-Montraveta: 0000-0003-4657-1805 